\title{
Suriyeli sığınmacı kadınların sözlü anlatılarında savaş, göç ve evlilik
}

\author{
War, migration and marriage with Syrian asylum seeker women's oral narratives
}

Muazzez Harunoğullar1 ${ }^{1}$

${ }^{1}$ Doç. Dr., Kilis 7 Aralı Üniversitesi, Fen Edebiyat Fakültesi, Kilis, Türkiye, e-mail: muazzez@kilis.edu.tr, ORCID: https://orcid.org/00000001-9515-7833

\begin{tabular}{|c|c|}
\hline Makale Bilgisi & $\ddot{O} z$ \\
\hline $\begin{array}{l}\text { Araştırma Makalesi } \\
\text { Gönderilme: } 11 \text { Temmuz } 2021 \\
\text { Düzeltme: } 9 \text { Ekim } 2021 \\
\text { Kabul: } 10 \text { Ekim } 2021 \\
\text { Anahtar kelimeler: } \\
\text { Suriyeli mülteciler, } \\
\text { Suriyeli kadınlar, } \\
\text { Göç, } \\
\text { Suriyeli gelinler, } \\
\text { Evlilik }\end{array}$ & $\begin{array}{l}\text { Çalışmanın amacı, Suriyeli kadınların savaş dolayısıyla yaşanan göçün yaşamları üzerin- } \\
\text { deki etkileri ile gündelik yaşam ve evlilik deneyimlerini değgrlendirmektir. Çalışma, kartopu } \\
\text { örnekleme yöntemi kullanılarak yapılmıştır. Bu yöntemle, Türkiye'nin sınır ili olan Kilis şeh- } \\
\text { rinde yaşayan ve Türk erkeklerle evlilik yapan } 15 \text { katılımcıya ulaşılmıştır. Veriler, katılım- } \\
\text { cılardan derinlemesine görüssme ve katılımcı gözlem tekniği ile elde edilmiştir. Savaşın ka- } \\
\text { dınların yaşamında ve psikolojilerinde meydana getirdiği etkiler oldukça derindir. Savaşta } \\
\text { ailesini veya eşini kaybeden ya da savaşın yarattığı tüm olumsuz şartlarla baş etmek zorunda } \\
\text { kalan kadınlar hayata tutunabilmek, güvenliklerini sağlamak, ekonomik anlamda rahatla- } \\
\text { mak, kendilerini bir yere ait hissetmek için Türk erkekleriyle evlilik yapmayı tercih etmiştir. }\end{array}$ \\
\hline
\end{tabular}

\begin{tabular}{ll}
\hline Article Info & Abstract \\
\hline Research Article & $\begin{array}{l}\text { The aim of the study is to evaluate the effects of war-related immigration on their lives, and } \\
\text { their daily life and marital experiences. The study was carried out using the snowball sam- } \\
\text { pling method with this method, } 15 \text { participants who married Turkish men have reached Tur- } \\
\text { key's border province of Kilis city. Data were obtained from the participants through in- } \\
\text { depth interviews and participant observation technique. The effects of war on women's life } \\
\text { and psychology are profound. Women who lost their family or husbands in the war or had } \\
\text { Revised: } 9 \text { October } 2021 \\
\text { to cope with all the negative conditions created by the war preferred to marry Turkish men } \\
\text { in order to hold on to life, to ensure their safety, to relax in economic terms, to feel them- } \\
\text { Keywords: } 2021\end{array}$ \\
$\begin{array}{l}\text { Syrian refugees, } \\
\text { Syrian women, }\end{array}$ & \\
Immigration, &
\end{tabular}

\section{Giriş}

Dünya'da 1945'li yıllardan önce de farklı coğrafyalarda iç savaş ve çatışmalar yaşanmış olmakla birlikte özellikle soğuk savaş döneminde ülke içi silahlı çatışmalarda büyük artış görülmüş soğuk savaştan sonra da bu artış devam etmiştir. Ekonomik seviyesi düşük ülkelerde, hükümetlerin düşürülmesi terörizmin güç kazanması, toplumsal ayrışmaların artması ve kaosun çıkması daha kolay gerçekleşmektedir. İç savaşlarda veya silahlı çatışmalarda halk etnik köken, dil, din, mezhebe göre bölünmektedir. Bu ayrışma alanlarına ülkelerin ekonomik yapıları ve düzeyleri, halkın gelir düzeyinin düşüklüğü, halk arasındaki gelir adaletsizliği de eklendiği zaman silahlı çatışma veya iç savaş çıkması için gerekli zemin hazırlanmış olur. Orta Doğu'da yaşanan silahlı çatışmalar veya iç savaşlar özellikle 2011 yılından sonra yaşanan insani krizlerle birlikte dikkat çekici bir hal almıştır. Ekonomik etkenler, halkın eşit haklar, özgürlük ve demokrasi talepleri, dış müdahaleler gibi faktörler Suriye'de iç savaşın çıkmasında etkili olmuştur. İç savaşla birlikte ülke içindeki terörist grupların faaliyetleri de artış göstermiştir.

* Araştırmanın verileri 2020 yılından önce toplanmıştır. Tüm taraflar kendi özgür iradeleriyle araştırmaya dâhil olmuşlardır. Tüm sorumluluk yazarına aittir.

Kaynak göster: Harunoğulları, M. (2021). Suriyeli sı̆̆ınmacı kadınların sözlü anlatılarında savaş, göç ve evlilik. International Journal of Social Sciences and Education Research, 7 (4), 353-368. DOI: https://doi.org/10.24289/ijsser.969897 
İç savaşlarda sivil nüfus ülke içinde ölüm, yaralanma, engellilik, hastalık riskini arttıran koşullara farklı derecelerde daha fazla maruz kalmaktadır. Uzun süren kanlı iç savaşlarda büyük nüfus kitleleri, onurlu, güvenli ve daha iyi hayat şartlarına sahip olmak için, yerlerinden edilerek mülteci durumuna düşmektedir. Son iki yılda dünya çapında can kaybının yanı sıra büyük zorluklar ve travmaya neden olan büyük göç ve yerinden edilme olayları yaşanmıştır. Suriye, Yemen, Orta Afrika, Demokratik Kongo Cumhuriyeti, Güney Sudan gibi ülkelerde yaşanan silahlı çatışmalar, aşırı şiddet veya şiddetli ekonomik ve politik istikrarsızlık nedeniyle milyonlarca insan yerinden edilmiştir. Ülkelerinde yaşanan şiddet ve çatışma sebebiyle ülke içinde yerinden edilmiş nüfus sayısı 41,3 milyona ulaşmışı̧ı. Bu rakam Yerinden Edilme İzleme Merkezinin izlemeye başladığı 1998 yılından buyana kaydedilen en yüksek rakamdır (IOM, 2020). 2011 yılında çatışmanın başlamasından bu yana dünyanın en kötü insani krizlerinden biri olmaya devam eden Suriye iç savaşı 21. yüzyılın en büyük insani felaketlerinden biridir. İç savaş sonucu milyonlarca insan mülteci konumuna düşmüş, ülke içinde milyonlarca insan yer değiştirmiş ve binlerce insan hayatını kaybetmiştir.

Mart 2011'de iç savaşın başlamasından bu yana milyonlarca Suriyeli vatan topraklarını, evlerini terk ederek komşu ülkelerin yanı sıra Kuzey Afrika (özellikle Mısır) ve Avrupa ülkelerine göç etmek zorunda kalmıştır. Suriye, 7,2 milyon $(7,245,754)$ nüfusu ile yerinden edilmiş kişi sayısının en fazla olduğu, küresel olarak en fazla sayıda mültecinin menşei ülkesidir. Savaşın dokuzuncu yılında 13,5 milyon Suriyeli, ülke içinde insani yardıma muhtaç duruma düşmüştür. Birleşmiş Milletler Mülteciler Yüksek Komiserliği'ne (BMMYK) göre, yaklaşık 5,7 milyon Suriyeli Türkiye, Lübnan, Ürdün, Mısır ve Irak'a zorunlu göç etmiş ve 6,6 milyonu Suriye içinde yerlerinden edilmiştir. 2,98 milyon kişi ulaşılması zor ve kuşatılmış bölgelerde yaşam mücadelesi verir hale gelmiştir. $\mathrm{Bu}$ arada yaklaşık bir milyonu Avrupa'ya sığınma talebinde bulunmuştur. Dünyada neredeyse 3,7 milyon $(3,626,734)$ Suriyeliye ev sahipliği yapan ülke Türkiye'dir (UNHCR, 2020; IOM, 2020). Suriye'de süren çatı̧̧malar sebebiyle Türkiye kitlesel mülteci akışına maruz kalmıştır. Özellikle Suriyeli nüfusun en fazla bulunduğu iller Türkiye'nin güney sınır illeridir. Bu illerden biri de Kilis'tir. Savaştan kaçan çoğu Suriyeli aile veya birey ekonomik açıdan oldukça zor şartlar içinde şehrin çeperlerinde ve şehir içindeki eski yerleşim alanlarında barınma imkânı bulmuş şehir halkıyla birlikte aynı mahallelerde aynı sokakları paylaşmaya başlamıştır.

\section{Literatür}

\subsection{Suriye'de kadin olmak}

Ataerkillik kültürü Kuzey Afrika'dan Orta Doğu'ya doğru yayılan bir yapıdır. Toplumsal cinsiyet ilişkilerini ataerkil kültürel yapı ile birlikte yerel gerçeklikler ve siyasi gündemler de inşa eder. Ataerkil kültür, erkeklere itaat eden ve açık direniş gösterme olasılığı daha düşük olan kadınları ifade etmektedir. Kadınların ve erkeklerin eylemliliğii, değişen koşullar ve zamanlarda farklı yerlerde farklı biçimler alabilir (Akyüz ve Tursun, 2019:33). Suriye toplumuna hâkim olan ataerkil yapının değerleri ve otoriter siyasi sistemin etkisiyle kadınlar hem ev içi hem ev dışı toplumsal cinsiyete dayalı şiddete maruz kalmaktadır. Yapılan araştırmalarda aile içi şiddetin yaygın olduğu ancak eşin cinsel istismarının yasal bir cezasının olmadığı belirlenmiştir. "Kişisel Statü Yasası"na (Personal Status Act No. 59 of 1953) göre, kadınlar evlilik, boşanma, velayet ve diğer aile meselelerinde söz sahibi değildir. Erkek eş, karısına ev dışında çalışmayı veya çocuklarıyla ülke dışına çıkmayı yasaklayabilir. Suriye'deki pek çok kadın, özellikle kırsal kesimde yaşayanlar, aile miraslarını erkek kardeşlerine devreder. Bu durum onların mali açıdan erkeklere bağımlılığını arttırmaktadır (Doumato, 2010:460;461).

Suriye toplumu kadınlardan, ev içi sorumlulukları üstlenmesini ve aile onurunu korumasını beklemektedir. Sosyal normlara uyulmaması kadınlara aile içinde ve toplumda baskı oluşturmakta ve bazı durumlarda bu durum cinayetle sonuçlanabilmektedir. Hem erkekler hem de kadınlar tarafindan benimsenen olumsuz sosyal tutumlar, kadınların mevcut firsatlardan faydalanmaktan kaçınmasında önemli rol oynamaktadır. Suriye'de kadın ve erkekler arasındaki sosyal ve toplumsal ayrımcllık evlilik ve çalışma hayatına katılım gibi konular başta olmak üzere pek çok alanda kendini göstermektedir. Kadınların itaatkâr ve ataerkil geleneklere bağllılı içeren geleneksel kişilik sergilemeleri toplum tarafindan beklenen bir durumdur. Bununla birlikte aile içindeki yaşlı kadınlar genellikle erkek aile üyeleri üzerinde önemli ölçüde etki sahibidirler (Doumato, 2010:461;479). Aile içi şiddetin yaygınlığı, bazı bölgelerde namus cinayetlerine müsamahakâr tavır, kadınların fiziksel güvenliklerine yönelik tehditlerle karşılaştığının ifadesidir. Kadınlar fiziksel ve psikolojik şiddet yanında cinsel şiddet ile de karşı karşıya kalabilmektedirler. Ataerkil ve muhafazakâr toplumlarda cinsel şiddetin etkileri çok boyutlu ve uzun vadelidir. Kadınların cinsel saldırıya uğramaları sonucu aile onuru zedelenmekte, mağdur edilenler toplumdan soyutlanmakta hatta ailenin şerefi için ailenin erkek bireyleri tarafından öldürülebilmektedirler (Ülgül, 2017:453). 
Toplumun temeli ailedir. Aile kurumu insan hayatına yön verir ve toplumu geleceğe hazırlar. Bu sebeple evlilik, aile kurumunun devamını sağlayan insan hayatının en önemli olaylarından biridir. Dünyanın farklı coğrafyalarında evlilik ile ilgili çeşitli mevzuatlar söz konusudur. Suriye toplumu Müslümanlar, Hristiyanlar ve Dürzilerden oluştuğu için evlilik mevzuatı da bu inançlara göre farklılık göstermektedir. Nüfusun \%80'inden fazlası Müslüman kabul edildiğinden Suriye'de en çok Müslüman aile hukuku etkindir. Her evlilik veya boşanmanın aile mahkemelerine kaydedilmesi gerekmektedir. Suriye geleneğine göre evlilikler, aileler arasında müzakere edilerek ve anlayışla ancak genellikle genç çiftlerin inisiyatifiyle düzenlenmektedir. Evlilik ile ilgili geleneklerde, kentsel ve kırsal alanlar arasında, sosyal sınıflar, başka etnik ve dini gruplar arasında önemli farklar bulunmaktadır (Landinfo, 2018:3-6).

Evlilik kararları ataerkil toplumlarda genellikle ailenin büyük erkekleri tarafindan verilmektedir. Evlilik çağına gelen bir erkek veya kız için eş arama sürecine sadece anne ve babalar değil aynı zamanda amcalar, dayılar, teyzeler, halalar, diğer akrabalar veya tanıdıklar dâhil olmaktadırlar. Erkek ve kız evlilik hakkında bilgilendirilmekte ve teklifi getiren kişi arabulucu olmaktadır. Müslüman kadınlar baba veya erkek akrabalarından evlilik vasilerinin izni olmadan evlenemezler. Evlilik sözleşmesi ancak bir veli ve iki tanığın imzasıyla gerçekleştirilmektedir. "Kişisel Statü Yasası"nın 20. maddesine göre yargıç, "dikkate almaya değer değilse" veli tarafından yapılan itirazları geçersiz kılabilmektedir. 27. maddeye göre, bir evlilik velinin izni olmadan akdedilirse, ancak kocanın uyumsuz görülmesi halinde evliliğin feshi talep edilebilir. Erkeklerin evlilik ehliyet yaşı 18, kadınlarınki ise 17'dir. Ancak hâkimler, reşit olmayan tarafın ergenliğe ulaştı̆ıını belirledikten sonra, 13 yaşındaki kızlar ve 15 yaşındaki erkek çocukların evlenmesi takdir yetkisine sahiptir (Doumato, 2010:466). Erkek ve kadının evlilikte farklı hakları ve yükümlülükleri bulunmaktadır. Erkek karısının barınma, giyecek, yiyecek ve tıbbi bakım dâhil olmak üzere nafakasını ödemekle yükümlüdür. Nafaka ödemesi kişinin mali durumuna göre belirlenmelidir ve zamanla değişebilir. Erkek aile reisi olarak kabul edilir, kadın kocasına itaat etmek zorundadır. İtaat, kadının kocasıyla birlikte yaşaması gerektiği anlamına gelmektedir. Kadın herhangi bir meşru sebep olmaksızın kocasıyla paylaştı̆̆ evden ayrılır veya kocasının ortak evine girmesini engellerse itaatsizlik olarak kabul edilmekte ve itaatsizlik etmeye devam ettiği sürece bakım hakkını kaybetmektedir. Kadın eşinin rızası olmadan ev dışında ücretli bir iş alırsa geçim hakkından mahrum olabilmektedir (Landınfo, 2018:12).

Suriye'deki İslami içtihat hukukuna göre "Kişisel Statü Kanunu", bir erkeğin belirli koşullarda aynı anda dört kadınla evlenmesine izin vermektedir. Ancak evlilik için meşru gerekçelerin olması gerekir. Ayrıca erkek aynı zamanda eşlerine aynı standartta bakmak ve onların barınmasını sağlamakla yükümlüdür. 18 yaşını doldurmuş her erkek herhangi bir neden belirtmeden karısından ayrılma hakkına sahip olduğu halde kadının benzer bir hakkı bulunmamaktadır. Kadının kocasından boşanma hakkının olması için evlilik sözleşmesinde bu durumun belirtilmesi gerekmektedir. Ayrıca eşler karşılıklı anlaşma yoluyla da boşanabilmektedirler (Landınfo, 2018:13;14). "Kişisel Statü Yasası”nın 14. maddesi, evlilik sözleşmesinde kadının, evlilik, ev dışında çalışma, evlilikten sonra eğitimine devam etme veya boşanma hakkını garanti altına alan hükümler koymasına izin vermektedir. Ancak özellikle kırsal kesimlerde okuma yazma bilmeyen pek çok kadın bu haklarının farkında değildir. Boşandıktan sonra, erkek çocuklar 13 yaşına, kız çocuklar 15 yaşına gelene kadar çocukların velayetini anne almaktadır. Eğer anne tekrar evlenmezse baba velayeti otomatik olarak kaybetmekte, şayet anne velayet için uygun olmazsa velayet babaanneye veya diğer kadın akrabalara verilmektedir. Suriye'de boşanan kadınlar toplum tarafından hoş karşılanmazlar. Boşanmış kadınlar evde veya düşük ücretli işlerde kayıt dışı olarak çalışma eğiliminde olduklarından, kocalarının mali desteği olmaksızın geçimlerini sağlamakta zorluk çekmektedirler. Boşanmış kadınların, ebeveynlerinin veya erkek akrabalarının evine dönmesi toplum tarafından daha kabul edilebilir bir durumdur. Yasal olarak ev kiralama ve kendi başlarına yaşama hakkına sahip oldukları halde, geleneksel olarak bu durum güvensiz veya uygunsuz değerlendirildiği için bekâr ya da evli kadınların bunu yapması oldukça nadir görülen bir durumdur (Doumato, 2010:467;481).

Ataerkil kültürün bir gereği olarak sosyal gelenekler, kadınların erkeklere bağımlı olacak şekilde uygulanmaktadır. Kadınlar için en uygun alan ev ve ailedir. Kamusal etkileşim alanının erkeklere ayrıldığı kabul edilir. Ancak kadınların eğitime erişimi arttıkça eğitimli kadın sayısında meydana gelen yükseliş ile birlikte iş gücüne katılım oranlarında da kadınlar lehinde olumlu bir gelişme yaşanmıştır. Zorlu ekonomik koşullarda aile gelirine kadınların katkı sağlamasıyla birlikte toplumun kadının iş hayatına katılmasına bakış açısında olumlu bir bakış açısı da gelişmeye başlamıştır. Toplumsal normlar nedeniyle kadınların yerel düzeyde kamusal alana katılmaları sınırlıdır. Kadınların eğitim seviyesi arttıkça ve aynı zamanda internet gibi haberleşme teknolojisinde yaşanan gelişmeler nedeniyle kadınlar medyaya daha fazla dâhil olmakta ve toplumsal cinsiyet algısı üzerinde daha büyük etki yapmaktadırlar (Doumato, 2010:479;481). 
Kadınlar gelirlerini kocalarıyla paylaşmak zorunda değillerdir, ancak Suriye'deki ekonomik durum sebebiyle ailenin sadece kocanın geliriyle yaşaması zor olduğundan pratikte neredeyse tüm çalışan kadınlar ailenin geçimine katkıda bulunmaktadır (Landınfo, 2018:13). Suriye'de kırsal kesimdeki kadınlar, kayıt dışı ve ücretsiz bir şekilde ev içi işlerde ve tarım işçiliğinde günde 15 saatten fazla çalışmaktadırlar. Bu sebeple kırsal kesimde kız çocuklarının okulu bırakma oranı yüksek olmaktadır. Suriyeli kadınların ancak \%3’ü ticarete katılmaktadır. Toprak ve makine mülkiyeti de \%3 civarındadır (Doumato, 2010:473).

Suriyeli aileler geleneksel olarak birbirlerine sıkı bağlarla bağlıdırlar. Savaştan önceki toplumsal düzende kadınlar tek başlarına alışverişe gitmez, ailelerdeki erkekler tarafından koruma sağlanırdı. Savaşla birlikte kadınların yaşam tarzları ve geleneksel aile yapılarında değişimler yaşanmaya başlamıştır. Parçalanan ailelerde, ailedeki erkeklerin öldürülmesi, hapsedilmesi veya ağır yaralanması, uzuvlarını kaybetmesi ile birlikte kadınlar korku dolu bir süreçte pek çok zorlukla karşı karşıya gelmişlerdir. Barınma ve temel yaşam malzemelerini karşılayabilmek için günlük yaşam mücadelesine giren maddi destekten yoksun kadınlar, küçük çocuklarının çalışmasına izin vermek ya da çocuklarıyla birlikte ev işleri veya tarlalarda çalışarak para kazanmak zorunda kalmışlardır.

Yaygın olan evlilik gelenekleri, yaşanan toplumsal dönüşümle birlikte büyük ölçüde değişime uğramıştır. İç savaş nedeniyle nüfusun bazı kesimlerinde evlilik ve boşanma kaydı yapılamamakta ve medeni durumu belgelemekte zorluklar yaşanmaktadır. Ayrıca yaşanan iç savaş bazı evlilik geleneklerinde değişikliklere sebep olmuştur. Kentsel ve kırsal alanlarda çok eşlilik görülmekle birlikte kırsal alanlardaki çok eşlilik oranı kentsel alanlara göre daha fazladır. 2011'de iç savaşın çıkmasıyla birlikte kadınlardan çok daha fazla sayıda erkek nüfus ölümü yaşandığından bazı bölgelerde çok eşlilik önemli ölçüde artış göstermiştir. Birçok aile iç savaş nedeniyle bölünmüştür. Eşleriyle yaşamayan birçok kadının aile defteri veya diğer uygun belgeleri yoktur. Medeni durumlarını güncellemek veya çocuklarını kaydettirmek isteyen kadınlar için birçok zorluk ortaya çıkmaktadır. Bazı kadınlar çeşitli isyancı gruplar için savaşan yabancı askerlerle evlilik yapmıştır. Yabancı uyruklu bir kişiyle evlilik, güvenlik servisinden izin gerektirdiğinden, bu tür evlilikler Suriye'de kaydedilmemiştir. Bu tür evliliklerden doğan çocuklar da kayıt altına alınamamıştır. Yaşanan bu zorluklar üzerine Şubat 2017'de "Suriye Medeni Durum Kanunu”nda değişiklik yapılmış, kocası olmayan kadınlara aile defteri verilmeye başlanmıştır (Landınfo, 2018:6;14;28).

\subsection{Suriyeli kadınlar, savaş ve göç}

Farklı coğrafyalarda yaşanan şiddetli çatışmalar, iç savaşlar milyonlarca insanın zorunlu olarak yer değiştirmesine yol açmaktadır. Bu durumdaki göç akışları bireylerin güvenli bir yaşama erişim düşüncesiyle kendini göstermektedir. Orta Asya ve Orta Doğu her zaman büyük göçebe popülasyonlarına sahip olmuştur. Ülke içi çatışmaların artması ve genişlemesi sonucu yaklaşan felaketlerle karşı karşıya kalan mülteci, ülkesinden ayrılmaya ve başka ülkelerde yaşamak için barınacak yer bulmaya çalışmaktadır. Savaş, silahlı çatışma, insan hakları ihlalleri, ekonomik zorluklar, kıtlık, doğal afetler gibi pek çok nedenden dolayı bireyler göç etmek zorunda kalmaktadırlar (Anker, 2002:6). Silahlı çatışmalarda kadınlar, savaşanlar tarafından daha fazla hedef haline getirilmekte ayrıca evlerini terk etmeye ve ilticaya zorlanmaktadır. Yaşanan savaş veya silahlı çatışmalarda sivil kayıplar meydana gelmekte sivil kayıpların neredeyse \%90’ına yakın kısmını kadın ve çocuklar oluşturmaktadır (Gürpınar, 2017:474).

Göç sürecine katılan kadınlar toplumun kendilerine yüklediği sorumluluklar nedeniyle süreç boyunca kadın olmanın mağduriyetini fazlasıyla yaşamaktadırlar. Toplumsal cinsiyet rolleri gereği kadınlar, bu süreçte en dezavantajlı ve en hassas grubu oluşturmaktadırlar (Sam, 2006:408). Sosyal dışlanma ve ölüm korkusu nedeniyle saldırıya uğrayan kadınlar yaşadıkları cinsel şiddet olaylarını başkalarıyla paylaşamamakta, psikolojik olarak yaşadıkları travma yıllarca sürmektedir. Hayatlarını geçirdikleri topraklarda güvenlikleri tehlikeye giren kadınlar tacize/tecavüze uğramamak için ülkelerinden kaçmak zorunda kalmıştır. Günümüz savaşlarında sivil alanlar/siviller hedef alınmakta ve silahların/bombaların makrohedefi haline gelmektedir. İç savaşların yaşanmasıyla birlikte sivil vatandaşlar kendi yaşamlarını sürdürebilmek için gerekli gıdaya yeterince erişemedikleri gibi aynı zamanda sağlık, eğitim, ulaşım gibi sosyal hizmetlerden de yeterince faydalanamamaktadırlar. Bu durumdan en fazla kadın ve çocuklar olumsuz yönde etkilenmektedir (Ülgül, 2017:453;446). Kuzey Afrika ve Orta Doğu'nun çeşitli yerlerinde yaşanan hükümetleri protesto dalgaları, Mart 2011'de Suriye'nin Deraa kentinde Esad rejimine karşı gösterilerin de yaşanmasına yol açmıştır. Gösterilere katılanlara ve çocuklara karşı rejim güçlerinin sert müdahaleleri ve protestoların rejim tarafından şiddetle bastırılması, halkın yaşam hakkının tehdit altına alınması iç savaşa sebep olmuştur. İç savaş doğrudan ve dolaylı olarak halk arasında hem kadınlar hem erkekler hem de çocuklar için yıkıcı deneyimler olarak kendini göstermiştir. Rejim güçleri tarafından gözaltına alınan kadın ve erkekler işkence görmüşlerdir. Erkeklerin savaşta ölüm ve yaralanma riski yüksek iken, kadınlar ev içi roller ve saldırı riskleriyle karşı karşıya kalmışlardır (Cankurtaran ve Albayrak, 2019:12). 
Kimliğin çoklu boyutları (sınıf, ırk, cinsiyet, etnisite, milliyet, cinsiyet hiyerarşileri gibi) insanları ve onların düşünme ve hareket etme biçimlerini şekillendirerek konumlandırmaktadır. Çalışmaların birçoğu kadınların ulusötesi iletişim kanallarına erişiminin erkeklerden çok daha sınırlı olduğunu ortaya koymaktadır (Mahler ve Pessar, 2001:446). Erkekler ve kadınların zorunlu göçe dâhil olmaları farklılık göstermektedir. 1990'lı yılların başında dünyada yaşanan savaşlarda eski Yugoslavya'da, Ruanda'da kadınlara yönelik yaygın cinsel şiddet suçu işlenmiştir. Yapılan araştırmalara göre kadınların "kurban", "barış yapıcı" olarak rollerinin doğallaştırılması ve buna karşılık erkeklerin "doğuştan" şiddetin daha geniş bir baskıcı ataerkil sistem içinde tasvirini yapıbozuma uğratmıştır. Yapılan çalışmalarda, sadece kadınların deneyimleri değil, aynı zamanda kız ve erkek çocukları ile erkeklerin kitlesel yerinden edilmesine yol açan çatışma durumlarına kadınların nasıl farklı bir şekilde dâhil oldukları ve bu durumlardan nasıl etkilendikleri araştırılmıştır. Araştırmalara göre kendilerinin doğrudan şiddet eylemlerine katılabilecekleri veya şiddet eylemlerini kışkırtabilecekleri, kadınların kurban ve erkeklerin fail olarak uzun süredir devam eden ikili tasvirlerin ötesine geçebileceği kabul edilmiştir. Ayrıca yapılan araştırmalarda savaşlarda yetişkin erkekleri ve erkek çocuklarını zorla askere alma, yargısız infaz ve cinsiyete özgü katliamlar için hedef alma ile birlikte belirli yetişkin erkeklerin ve erkek çocukların cinsiyete özgü şiddet ve zulme karşı savunmasızlıklarının giderek daha da arttığı belgelenmiştir. Srebrenitsa'da toplu halde öldürülen Müslüman erkeklerin oranı hayli fazladır. Yerinden edilme durumlarında erkeklerin cinsel şiddet (tecavüz, cinsel sakatlama) deneyimleri giderek daha fazla belgelenmektedir (Fiddian-Qasmiyeh, 2014:399).

Mart 2011'den Mart 2020'ye kadar Suriye'de öldürülen sivillerin 226,247'sinden 28,394'ünün kadınlar olduğu yayınlanan raporlarda yer almıştır. Bunların 16,062'si yetişkin kadın iken, 12,332'si ise 18 yaşından kü̧̧ük kız çocuklarıdır. Kadınların hedef alınmasıyla savaşların toplumlarda meydana getirdiği tahribat çok daha yüksek seviyede kendini göstermiştir. Suriye iç savaşında özellikle cinsel şiddete maruz kalan kadınların sayısı oldukça fazla olmakla birlikte böyle bir şiddete maruz kalma riski savaş alanındaki tüm kadınlar için söz konusudur (Syrian Network for Human Rights, 2020). Suriyeli kadınlar savaşla ilgili bir duruş benimsemiş, protesto ve grevlerin başlatılmasında, tutuklanan aile üyelerinin serbest bırakılmasında ve devlet şiddetinin sona ermesi çağrısında bulunarak önemli roller üstlenmişlerdir. Kadınların rejime karşı protestolara destek vererek, kamusal alanda üstlendikleri rolleri bastırmak için hükümet, güvenlik güçleri ve ordu tarafından kadına yönelik şiddeti sistematik olarak bir baskı aracı olarak kullanmış, taciz ve tecavüz yoluna başvurulmuş hatta muhalif güçlere karşı bu yaklaşım silah olarak kullanılmıştır. Taciz ve tecavüze uğrayan kadınlar toplumsal, kültürel ve dini yönden damgalanma gibi bir durumla karşı karşıya kalacaklarından mağdur edilen çoğu kadın tecavüz vakalarını bildirmemeyi tercih etmektedir. 2011-2015 yılları arasında yapılan bir araştırmada 142 tecavüz vakası belirlenmiş, tecavüzlerin çoğunun mağdur kadınlar gözaltındayken veya ceza evindeyken diğer kısmının ise ev baskınları ve adam kaçırma olaylarında yaşandığı belirtilmiştir (Cankurtaran ve Albayrak, 2019:12).

\subsection{Suriyeli kadınlar ve evlilik}

Barınma, gıda, sağlık, eğitim gibi temel ihtiyaçların karşılanmasında büyük zorluklarla karşılaşan Suriyeli kadınlar bu zorluklarla baş etmek için ev sahibi ülkede büyük bir hayat mücadelesinin içine girmişlerdir. Bilhassa tek başına yaşayan kadınların bir kısmı cinsel istismarın hedefi haline geldiklerinden güvenliklerini sağlamak için evlenmeyi tek çıkar yol olarak görmüşlerdir. Kadınların güvenlik, barınma ve gıda ihtiyaçları evlilik sayısında bir artışa sebep olmuştur. Aileler, kız çocuklarını korumak ve ekonomik anlamda rahatlamak maksadıyla reşit olmayan Suriyeli kız çocuklarını evlendirme yoluna gitmiş ve bu sebeple 18 yaşından kü̧̈ük kız çocuklarının evliliklerinde bu süreçte bir artış yaşanmıştır (Ülgül, 2017:453). İç savaş, evlilik modellerinin değişmesinde en önemli faktörlerin başında gelmektedir. Komşu ülkelerde Suriyeliler ile ev sahibi toplum arasında evliliklerin sayısı hızla artı̧̧ göstermiştir. Türkiye, Lübnan ve Ürdün'de çok sayıda Suriyeli kadın, ev sahibi ülkeden erkeklerle evlilik yapmaktadır. Zorunlu göçün toplumsal etkilerinden biri de Suriyeli kadınların Türk erkeklerle evlilikleri olmuştur. Türkiye'de TÜIK verilerine göre 2019 yılında yabancı gelinler arasında \%14,5 ile Suriyeli gelinler birinci sırada yer alırken Suriyeli gelinleri \%11,7 ile Azerbaycanlı gelinler ve \%10,5 ile Alman gelinler takip etmiştir (Şekil 1).

$\mathrm{Bu}$ süreçte Avrupa ülkelerinde yaşayan Suriyeliler ile Avrupalılar arasındaki evlilik sayısında da artış yaşanmıştır. Ayrıca Suriyeliler arasındaki boşanma oranında da güçlü bir artış meydana geldiğini de göz ardı etmemek gerekir. Mülteciler arasında birçok Suriyeli erkeğin, eşlerini terk etmesi, ailelerine destek olmayı bırakması veya başka bir şekilde baba olarak yükümlülüklerini yerine getirmemesi söz konusu olmuştur. Bazı kadınlar kocalarının davranışlarını kabul etmeye hazır olmadıklarından boşanmayı tercih etmiştir. Komşu ülkelerdeki mülteciler arasında Suriyelilerle yabancı uyruklular arasında evliliklerin sayısı artmakla birlikte, küçük yaştaki Suriyeli kızların ev sahibi ülkedeki yaşı büyük erkeklerle evliliklerinin sayısında da artış görülmüştür. Bu durumun arkasındaki nedenler ne kadar karmaşı olsa da kısmen yoksulluk ile genç kadınların ve ailelerinin maddi açıdan geleceğini koruma ihtiyacı ile açıklanmaktadır (Landınfo, 2018:30-31). 


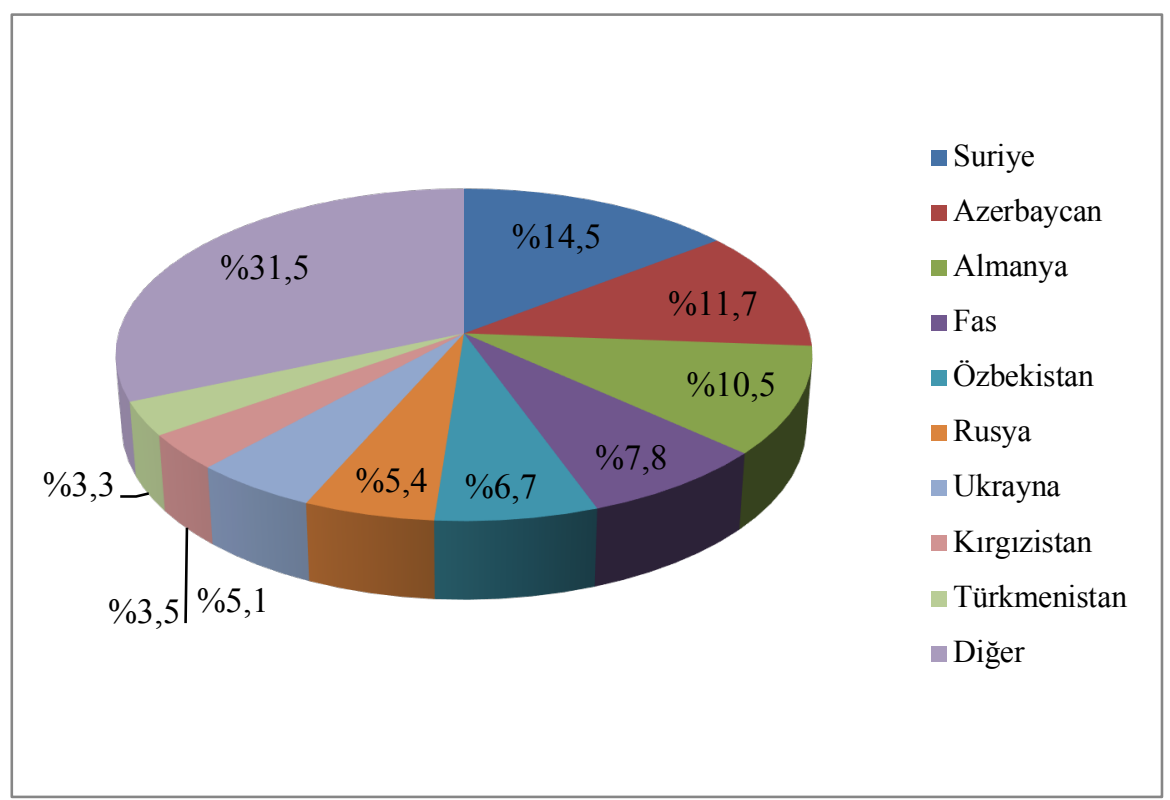

Şekil 1. Türkiye'deki yabancı gelinlerin oranı, 2019. Kaynak: TÜİK, 2020

Suriye büyükelçilikleri genellikle yurtdışında gerçekleşen evliliklerin ve doğumların kayıtlarına yardımcı olmaktadır ve Suriye'de doğru bir şekilde kaydedilmesini sağlamaktadır. Ancak uygulamada komşu ülkelerdeki birçok Suriyeli mülteci, Şam'daki yetkilileri artık tanımadıklarından, kendilerine veya Suriye'de bulunan aile üyelerine karşı olumsuz tepkilerden korktuklarından veya aile üyelerinden birinin askerlik hizmetinden kaçtığ 1 için büyükelçilikle temasa geçmekten çekinmekte bu konuda isteksiz davranmaktadır. Birçok kişi ev sahibi ülkelerde evlilik işlemleri ve yeni doğan kayıtlarının rutinlerine aşina değildir. Suriye dışında iki Suriyeli arasında yapılan resmi olmayan evliliklerde evliliğin Suriye'de tescil edilmeden önce ev sahibi ülkede tescil ettirilmesi gerekmektedir. Bazı Suriyeliler, Suriye'deki Şeriat mahkemesine doğrudan başvurarak veya bir vekil tayin ederek evliliklerini olağan bir şekilde geriye dönük kaydettirebilmişlerdir. Türkiye'de bilinmeyen sayıda Suriyeli mülteci bu prosedürden yararlanmıştır (Landınfo, 2018:29).

Suriye'den Türkiye'ye göç etmek zorunda kalan Suriyeli kadınlar, ev sahibi toplum tarafindan kabul edilme, güvenli ve sağlıklı bir yaşam mekânına kavuşma, ekonomik sıkıntıların üstesinden gelme gibi sebeplerle sınır ötesinden farklı kültüre mensup erkeklerle evlilik yapmayı tercih etmiş̧ir. Kilis şehrinde yapılan saha çalışmasında, Türk erkeklerle ilk evliliğini yapan Suriyeli kadınlar olduğu gibi kendi ülkesinde daha önce evlilik yapmış ancak ölüm veya boşanma gibi bir nedenle yalnız yaşayan Suriyeli çocuklu kadınlar da kendileri gibi olan Türk erkekleriyle ikinci evlilik akdini gerçekleştirmiştir. Suriyeli aileler yaşadıkları coğrafyada karşılaştıkları yaşamsal zorluklar sebebiyle kızlarının daha iyi hayat şartlarına kavuşması için kızlarını yerli erkeklerle evlendirmeyi uygun görmektedir. Kilisli damatları olan Suriyeli sığınmacılar ise onların desteğini almaktadırlar. Suriyeli sığınmacıların aile yapıları Türklerin aile yapılarından farklılık göstermektedir. Suriyelilerde 18 yaşın altındaki bireylerde erken evlilikler de görülmektedir. Kültürel olarak yaşanan bu durum Kilis şehrinde yaşayan Suriyeli sığınmacılarda özellikle son yıllarda bir değişim göstermektedir. Gelinen coğrafyanın yapısı ve Suriyeli genç kızlarda üniversiteye gitme sayısındaki artış nedeniyle Suriyeli sığınmacılarda erken yaşta evliliklerde bir azalma ve kadınların aile içindeki rollerinde de bir dönüşüm yaşanmaktadır.

\section{Yöntem}

Bu çalışmada, Suriye iç savaşından kaçarak Kilis'e gelen ve burada evlilik yapan "Suriyeli kadınların" savaş ve göç esnasında yaşadıkları ile evlilikleri, hayat hikâyeleri temelinde ele alınmıştır. Diğer bir ifadeyle bu araştırmada kadın sığınmacıların ülkelerinde yaşadıkları savaş durumu, savaştan kaçış, göç ve ev sahibi toplumda yeni bir yaşam inşa etme mücadelesinde aldıkları evlilik kararları, kendi anlatıları doğrultusunda değerlendirilmiştir. Çalışma alanını, Türkiye-Suriye sınırında yer alan Kilis şehri oluşturmaktadır. Çalışmanın verileri, 2019 yılının bahar ve yaz aylarında yapılan saha çalışmasında Türk erkekler ile evlilik yapan 15 Suriyeli kadınla yapılan derinlemesine görüşmelerle ve katılımcı gözlem tekniğiyle elde edilmiştir. Araştırmada nitel gözlem metotları uygulanmıştır. Suriyeli kadınlara yerel ağlar aracılığıyla kartopu yöntemi kullanılarak ulaşılmıştır. Görüşmelerden bazılarına eşler de iştirak etmiş, evlilik kararı, Suriyeli kadınla aile kurma, aile bireylerinin birbirleriyle uyumu ile ilgili eşlerin de görüşleri alınmıştır. Suriyeli kadınlardan 5'i Türkmen kökenli olduğu için bu kişilerle görüşmeler 
Türkçe gerçekleştirilmiştir. Diğer 10 Suriyeli ile Arapça bilen bir kadın tercümandan destek alınarak iletişim kurulmuştur. Bu 10 kadının da Türkçeyi anladıkları ancak kendilerini yeterli şekilde ifade edemediği bununla birlikte Türkçe dilini öğrenme konusunda mesafe kat ettikleri gözlenmiştir. Çalışmaya katılan Suriyeli kadınların yaşları 17 ila 40 arasında değişmektedir. Görüşmecilere kişisel bilgiler edinmeye yönelik sorular ile savaş öncesi durum, göç, ev sahibi toplumda yaşadıkları ve evlilikleri ile ilgili sorular da sorulmuştur. Görüşmecilerin sorulan soruları yanıtlarken kendilerini rahat hissetmeleri için görüşmeler sohbet havasında gerçekleştirilmiştir. Görüşme yapılan kadınların tamamı sorulan soruları yanıtlamaktan çekinmemiştir. Çalışmada görüşmecilerin güvenliği ve özel hayat gizliliği dikkate alınarak isimleri kullanılmamıştır. Katılımcılar K1, K2, K3 ... şeklinde ifade edilmiştir.

\section{Bulgular}

\subsection{Katılımcıların demografik özellikleri}

Görüşme yapılan katılımcıların yaşları 17 ila 40 yaş aralığındadır. Kadınların 5’i Suriyeli Türkmen, 10’u ise Arap kökenlidir. Katılımcıların eğitim seviyesi eşleriyle farklılık göstermekle birlikte 6 katılımcının eğitim seviyesi eşinden daha yüksektir. 2 katılımcı dışında diğer tüm katılımcılar ev hanımıdır. Eşleri farklı iş kollarında çalışmaktadırlar (Tablo 1).

Tablo 1. Görüşülen çiftlerin demografik bilgileri

\begin{tabular}{lccll}
\hline Kat1lımc1lar & Yaş & $\begin{array}{c}\text { Etnik Köken } \\
\text { Suriyeli Kadın/Eşi }\end{array}$ & $\begin{array}{l}\text { Eğitim } \\
\text { Suriyeli Kadın/Eşi }\end{array}$ & $\begin{array}{l}\text { Meslek } \\
\text { Suriyeli Kadın/Eşi }\end{array}$ \\
\hline K1 & $22 / 31$ & Arap/Türk & Ortaokul/ İlkokul & Ev hanım1/ Memur \\
K2 & $36 / 69$ & Arap/Türk & Okuryazar değil/Illkokul & Ev hanım1/ Emekli \\
K3 & $30 / 50$ & Türkmen/Türk & Okuryazar değil/Illkokul & Ev hanım1/ Yorganc1 \\
K4 & $30 / 33$ & Türkmen/Türk & Lise/Ortaokul & Ev hanım1/Toptanc1 \\
K5 & $36 / 43$ & Türkmen/Türk & İlkokul/İlkokul & Ev hanım1/ Lokantac1 \\
K6 & $18 / 23$ & Türkmen/Türk & Ortaokul/ Yüksekokul & Ev hanım1/Güvenlik Görevlisi \\
K7 & $17 / 23$ & Arap/Türk & İlkokul/Lise & Ev hanım1/ Esnaf \\
K8 & $25 / 40$ & Arap/Türk & Üniversite terk/Illkokul & Ev hanım1/ Esnaf \\
K9 & $20 / 26$ & Türkmen/Türk & İlkokul/Ortaokul & Ev hanım1/ Frrınc1 \\
K10 & $40 / 41$ & Arap/Türk & Üniversite/İlkokul & Öğretmen/ Kebapç1 \\
K11 & $19 / 23$ & Arap/Türk & Ortaokul/ İlkokul & Kuaför/ Sebzeci \\
K12 & $30 / 46$ & Arap/Türk & Ortaokul/Lise & Ev hanım1/ Lokantac1 \\
K13 & $30 / 30$ & Arap/Türk & Okuryazar değil/Ortaokul & Ev hanım1/ Berber \\
K14 & $18 / 28$ & Arap/Türk & Lise/Ortaokul & Ev hanım1/ Firınc1 \\
K15 & $25 / 32$ & Arap/Türk & Ortaokul/ Ortaokul & Ev hanım1/Kalıp̧̧1 \\
\hline
\end{tabular}

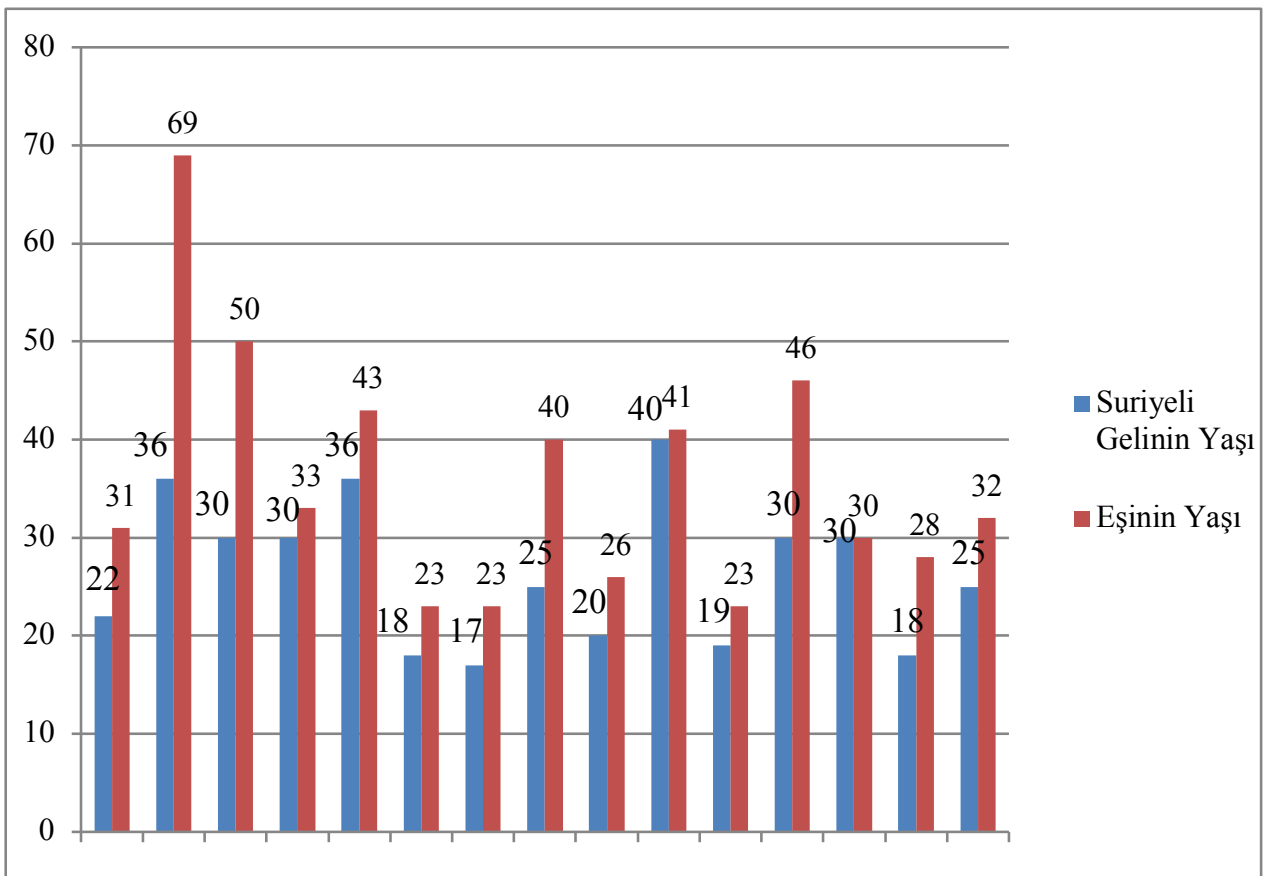

Şekil 2. Suriyeli kadınlar ile eşlerinin yaşları. 
Katılımcı kadınların yaşları ile eşlerinin yaşı arasındaki yaş farkı en çok 33 olmakla birlikte yaş farkı hiç olmayan çiftler de bulunmaktadır. Suriyeli kadınların yaşları genelde eşlerinden küçüktür (Şekil 2).

Suriye iç savaşı milyonlarca insanın sosyal-toplumsal yapısını doğrudan etkileyerek hayatlarının her alanında dramatik değişiklikler yaşamalarına yol açmıştır. Savaştan önce yaşadıkları yerleşmelerde rahat bir hayat süren, yakın arkadaşları, akrabaları, aileleri, sosyal destek ağları ile evlerini yöneten erkekler tarafindan desteklenen kadınlar birdenbire tüm bu destek ağlarından mahrum kalmış, zor şartlar karşısında tek başına veya çocuklarıyla hayatta kalma mücadelesi vermeye başlamışlardır. 2011'de meydana gelen şiddetli çatışmalar ile birlikte parçalanan Suriye toplumunda çoğunluğunu kadın ve çocukların oluşturduğu kitleler hayata tutunabilmek için sınırlar dışına yeni bir ülkeye kaçmak zorunda kalmışlardır.

Avrupa'ya göç etmek için ülkelerinden kaçan kadınların bir kısmı, Suriye'deki silahlı gruplarca kontrol altında tutulan güvenlik noktalarında cinsel saldırıya uğramıştır. Sınırdan güvenli bir şekilde geçilse bile komşu ülkelere ulaşan kadınların birçoğunun eşlerinin savaşta ölmesi veya sakat kalması sebebiyle ailenin tüm yükünü üstlenen kadınlar aile reisliği rolünü de üstlenmek zorunda kalmışlardır (Ülgül, 2017:453).

"Savaş esnasında tüp yok, yakacak yok, evde yokluk başladl. Ocakta yemek yapmaya çallşlyorduk. Gece sokă̆a çıkma yasă̆ vardı. Gece hırsızlar veya DEAŞ (Devlet'ül Irak ve'ş Şam) örgütüne ait kişiler evlere baskın yapıyorlar, çocukları (kı-erkek fark etmez) alıp götürüyorlardı. Ailem, kız kardeşim ve benim kaçırılmamdan, kardeşlerimin DEAŞ tarafindan kaçırılacağından korktukları için göç etmeye karar verdik. " (K7).

Suriyeli savaş mağdurları evlerini, akrabalarını, arkadaşlarını, mallarını geride bırakarak yanlarına gerekli çok az eşya alarak bilinmez bir yolculuğa çıkmışlardır. Milyonlarcası mülteci olarak yaşayacak bu insanlar, kendi toplumlarından, destek kaynaklarından çok uzaklarda kendileri ve aileleri adına tek başlarına karşılarına çıkan tüm zorluklarla yüzleşmek zorunda kalmışlardır. Görüşme yapılan kadınların çoğu yaşadıkları yerlerde çatışmaların şiddeti arttığı ve hayatları tehlikeye girdiği zaman kaçmayı tercih ettiklerini ifade etmişlerdir.

"Savaşta dayımı, amcamı ve amcamın torunları hayatlarını kaybetti. Savaşın çıktığ ilkyıllarda çatışmalar artınca annem ve babam bizleri alıp Türkiye'ye getirdiler. Suriye'deki evimiz aile apartmanıydı. Büyük 5 katlı bir apartman. Çatışmalar çıkınca Esad askerleri evleri boşalttılar. Askerler binaları boşaltınca aileden 4 kişi kaldı diğerleri Türkiye’ye geldi. Sınıra yakın bir yere kadar tampon bölgesine geldik. Tampon bölgesinden bu tarafa yürüyerek geçtik. Kış mevsimi olduğu için üstümüz başımız hep çamur içinde kaldı. Yanına geldiğimiz akrabalarımız çok kalabalık olduğu için kadınlar çok zorlandı. Kilis 'te babamın önceden kiraladığı eve yerleştik." (K6).

Yapılan görüşmelerde Suriyeli kadınların göç etme nedenleri ile ilgili bulgular 8 madde halinde sıralanabilir. Bunlar;

1. Ülkelerindeki totaliter rejimlerin baskısı

2. Ülkedeki kaos ve savaş ortamından kaçma isteği

3. Rejim askerlerinin ve terör örgütlerinin saldırıları

4. Kadınların saldırılara ve cinsel istismara uğraması veya uğrayabilme korkusu

5. Fişleme ve tutuklamaların artması

6. İşkence ve şiddet

7. Hava saldırıları

8. Barış ve güven ortamında huzur içinde yaşama isteği

"Savaş esnasında eşim ve çocuklarımla evde otururken bombalar üstümüze yağdl. Bombalar yüzünden eşimi ve akrabalarımı kaybettim, annem ve babam ayrı oldukları için bana sahip çıkmadılar. Kız kardeşim savaşta atılan bombalarla sakat kaldı. Evde çocuklarımla yalnız kaldım. Bir taraftan üstümüze bombalar yağıyor diğer taraftan DEAŞ korkusundan sokağa çıkamıyorduk. DEAŞ’liler sokağa çıkmamıza izin vermiyorlardl. Bir gün sabah saat 7'de evimize bomba düştü evimizin kalan kısmı da yıkıldı. Illk eşimin 16 yaşındaki oğlunu, komşularımızı, komşularımızın çocuklarını DEAŞ öldürdü. DEAŞ düğün yapmayı, bayramlaşmayı yasaklamıştı. Ziyneti olan kadınların ziynetini zorla alıyorlardı. Rejim uçakları sürekli olarak yerleşme yerlerini, evleri bombalıyordu. Azez'de Afrin'de devlet yoktu, orada yönetim çeşitli örgütlerin elinde bulunuyordu. Savaş koşulları ve kimsesiz kaldığım için eşim öldükten 4 ay sonra göç kararı aldım. 
Daha sonra aile bireyleriyle kaçarak Halep'e gittik. Azez ile Halep arasındaki uzaklık 1 saat olduğu halde biz DEAŞ korkusundan ancak 24 saatte varabildik. Yol boyunca saklandlk. Eski kocamin ilk eşinden olan kizl, kiz kardeşim, erkek kardeşim ve iki çocuğumla birlikte 2013 yllında Türkiye'ye göç ettik. Kilis'te tanıdıklarım vardı ve memleketim Azez'e yakındı. Azez'den akşam saat 8'de yaya olarak yola çıktık. Zorlu bir yolculuktan ve yaşadığımız korku dolu saatlerden sonra gece saat l'de Kilis'e ulaştık." (K2).

"Yaşadığımız sokağa bombalar yağdı, çocuklar gözlerimin önünde hayatlarını kaybettiler." (K1). "Savaş çıtıtıtan sonra Suriye'de tek başıma kaldım, annem ve babam bana sahip çıkmadı." (K2). "Halep'te Esad'ın uçakları tarafindan şehrimize bombalar atıldl." (K3). "Komşularımın, yakın akrabalarımın evleri bombalandl." (K4).

"Suriye'de kirada oturuyorduk, evimiz bombalandı ve yıkıldl, ailece evin içindeydik. Yıkıntılar arasından çıktık. Komşularımızın kanlı cesetlerini gördüm, çok korktum, korkudan hastalandım. İki kardeşim Kilis'e geldiler, 2 ay çalıștlar, ev kiraladılar sonra biz geldik. Ailemin pasaportu var, pasaportla geldik, araba kiraladık, 1 saatte sinıra ulaştık." (K8).

"DEAŞ'liler evlere baskın yapıp kız ve erkek çocuklarını kaçırıyorlardı. Ailem bizim güvenliğimizi sağlamak için göç kararı aldı. Halep'ten 9 kişi parasız yola çıtktı, Şımeli köyüne geldik, o zaman ben 12, en büyük kardeşim 15 en küçük kardeşim 4 yaşındaydl. Göç eden diğer insanlarla birlikte gece yarısı minibüsle yola çıktık. Şımali köyüne babaanneme geldik. Babaannem bizi istemeyince Kilis'e göç ettik. Gö̧ esnasında Esad'ın askerleri, DEAŞ, PYD/YPG örgütleri yolda arama yaptılar, geçmemize izin verdiler. Sinır kapısindan geçerek Kilis'e girdik ve oturduğumuz mahalleye geldik. Sinırdan tellerden farklı sinır bölgelerinden insanlar Kilis'e geçtiler. Kilis'e geldikten sonra camiye ait bir evde 6 ay kaldlk. Sonra tek başına yaşayan 75 yaşındaki yaşlı bir kadına bakmak için onun yanına yerleştik. O evde 1 yll yaşadık. Yaşlı kadının evinde kira vermeden oturduk. Sonra babam akrabalartyla bir ev satın ald. Kendi evimize geçtik. Kilis'i kendi vatanim gibi hissediyorum."(K7).

Katılımcıların Kilis'e gelişleri 2012 ila 2015 yılları arasında olmakla birlikte özellikle 2012 ve 2013 yıllarında gelenlerin sayası daha fazladır. Katılımcıların geldikleri yerler dikkate alındığında 9'u Halep, geri kalanı ise Azez'den gelmişlerdir. Kilis'i tercih nedenleri, birçoğunun Kilis şehrinde akraba ve tanıdıklarının bulunması, coğrafi yakınlık ve ulaşım kolaylığının olmasıdır.

"Suriye'deyken yaşadığımı yere bombalar atıldl, yiyeceğimiz kalmadl, çok zor durumda kaldık. Bombalar altında yola çıktık yürüyerek sinıra ulaştı köyümüz sınıra yakındı. Gece yarısı sınırı geçtik, 4 metre hendekten, mayınlı araziden geçtik." (K9).

Ayrıca görüşmecilerden 4'ü, Kilis'ten evlilik için gelen erkeklerle taşınıp onların evlilik teklifini kabul ederek evlilik akdi yaptıktan sonra Kilis'e gelip yerleşmişlerdir (Tablo 2). Bu kişilerin eşleri kendilerine aracılar vasıtasıyla ulaşmış, ayrıca bu aracılara 1000 ila 2000 TL arasında aracılık ücreti ödemişlerdir. Tüm gelinlerin başlık parası alma gibi bir durum söz konusu olmamış, onlar için Türk bir erkekle evlenip yaşamlarını güvenceye almaları yeterli gelmiştir. Eşlerin tamamı birbirlerini görerek anlaşarak evlilik kararı almıştır. Görüşülen kadınların tamamı kendi iradeleriyle eş seçimi yaptıklarını belirtmiş̧lerdir.

Tablo 2. Suriyeli gelinlerin Kilis'e geliş yılları ve Kilis'i tercih nedenleri.

\begin{tabular}{|c|c|c|c|}
\hline Katılımcilar & Geliş y1lı & Geldikleri yer & Kilis'i tercih nedenleri \\
\hline K1 & 2014 & Halep & Coğrafi yakınlık \\
\hline $\mathrm{K} 2$ & 2013 & Azez & Tanıdıkların olması \\
\hline K3 & 2013 & Halep & Evlilik \\
\hline K4 & 2012 & Halep & Evlilik \\
\hline K5 & 2013 & Azez & Akraba ve tanıdıklarının olması \\
\hline K6 & 2012 & Halep & Akraba ve tanıdıklarının olması, coğrafi yakınlık, ulaşım kolaylığı \\
\hline K7 & 2013 & Azez & Akraba ve tanıdıklarının olması, coğrafi yakınlık, ulaşım kolaylığı \\
\hline K8 & 2014 & Halep-Heretan & Akraba ve tanıdıklarının olması, coğrafi yakınlık, ulaşım kolaylığı \\
\hline K9 & 2012 & Azez & Akraba ve tanıdıklarının olması, coğrafi yakınlık, ulaşım kolaylığı \\
\hline $\mathrm{K} 10$ & 2015 & Halep-Heretan & Coğrafi yakınlık, ulaşım kolaylığı \\
\hline K11 & 2012 & Halep & Coğrafi yakınlık, ulaşım kolaylığı \\
\hline K12 & 2013 & Halep & Coğrafi yakınlık, ulașım kolaylığı \\
\hline K13 & 2013 & Azez & Evlilik \\
\hline K14 & 2012 & Azez & Akraba ve tanıdıklarının olması \\
\hline K15 & 2012 & Halep & Evlilik \\
\hline
\end{tabular}




\subsection{Suriyeli kadınların evlilik nedenleri}

Suriyeli sığınmacı kadınlar, göç sürecinin dezavantajlarından kendilerini korumak için destinasyonlarda yerel toplumdan erkeklerle hem örfi/dini hem de hukuki olarak evlilik akdi yapmaktadırlar. Yapılan çalışmada Suriyeli kadınların Türk erkekleriyle evlenme nedenleri 7 başlık altında toplanmıştır. Bunlar:

1. Güvenli bir yaşam isteği

2. Daha iyi hayat koşullarına erişim

3. Toplumsal kabul görme

4. Özgür yaşama isteği

5. Çocuklu kadınların çocuklarına güvenli bir gelecek sağlama isteği

6. Türk erkeklerinin Suriyeli erkeklerden daha anlayışı ve duyarlı olduğunun düşünülmesi

7. Eşi tarafından değerli görülme arzusu

Suriyeli kadınların bir kısmı için yaptıkları evlilikler zorunluluktan olsa da hepsi için benzer durum söz konusu değildir. Yapılan saha çalışmasında görüşme yapılan kadınlardan bazıları bizzat evlilik nedeniyle Kilis'e geldiklerini ifade etmiştir.

“Türkiye'ye evlenmek için geldim. Evlilik nedeniyle eşim Suriye’ye geldi beni gördü beğendi ben de onu beğendim. Kocamla evlenmek hiç aklında yokken Halep ’in Diden köyüne gidip kendisini gördüm ve beğendim. Kendi isteğimle evlendim, kocamın 2. eşiyim. Evleneceğimiz zaman ailem beni sınıra getirip sinır kapısından Kilis'e geçirdi. Kilis'te nikahımız kıyıldı. Resmi nikah yapmak için Suriye'de nüfus idaresinden belgeleri getirebilmek amacıyla gidiş geliş yapan araçlara 2 kez para verdik. Belgelerin Türkiye 'ye gelmesi 2 yıl sürdü. Belgeler İstanbul'a konsolosluğa gelip burada işlem yapıldıktan sonra Kilis'e gönderildi. 2 yılın sonunda resmi nikahım yapılmış oldu. Resmi nikahlı olarak 3 yılımı tamamladığım takdirde Türk vatandaşlı̆̆ına geçebileceğim.” (K3).

Farklı iki etnik grup arasındaki evliliklerin yapılmasında evlilik yapacak kadının ailesi, akrabaları, aracılar, tanıdıklar gibi farklı kesimler etkin rol oynamıştır. Görüşme yapılan Suriyeli kadınların hemen hepsi evlilik yapacakları bireylerle tanıştırılmış ve daha sonra kendi istekleri dahilinde evlilik yapmışlardır. Bir aracı ya da aile bireyleri tarafından erkek ve kadınların birbirleriyle tanıştırılmaları ve verilen kararlar sonucu evliliklerin yapıldığ tespit edilmiştir.

Evlilik kararı almada ailenin erkekleri kadar evlilik yapacak kadının da evlilik kararı almada söz hakkı bulunmaktadır. Tanıdık olmadıkları farklı bir sosyal ortamda, alışılmadık toplumsal ve sosyal yapıyla yeniden hayatlarını inşa etmek isteyen kadınlar için aldıkları evlilik kararı oldukça önemlidir. Evlenecek kadın ya da erkeğin kişisel özellikleri ve bireysel tercihler de yapılan evliliklerde etkendir.

"Suriye'de iken annem ve babam olmadı̆̆ için abim, yengem ve yeğenlerimle birlikte yaşardım, orada kadınların dışarı çıkması pek söz konusu değildir. Eşim beni öksüz ve yetim olduğum için ve ayrıca çocuklarına annelik yapabileceğim için tercih etti. Öksüz büyüdüğüm için eşimin çocuklarına kol kanat gerdim.

Kendi çocuklarım kabul ettim. Eşsimin 5 yaşındaki kızı bana anne derken 8 yaşındaki erkek çocuğu bana abla diye hitap ediyor. Eşimle rahat ve huzurluyum. Tatil için İmir'e gitme planları yapıyoruz." (K1).

Yoksulluk, kişinin herhangi bir özrünün bulunması ya da evlilik yaşını geçirmiş olması gibi nedenlerle Kilis’te evlenme olasılığı bulunmayan veya Kilisli kadınları tercih etmeyen erkekler için Suriyeli kadınlar bu firsatı sağlamaktadır. Görüşme esnasında Suriyeli kadınların Türk erkekler tarafından neden tercih edildiği sorusuna yanıtlayan Kilisli damatlara göre onları Suriyeli kadınlarla evliliğe iten en önemli etmenler; Suriyeli kadınların Türk kadınlarına göre eşlerine karşı daha itaatkar olması, onların isteklerini her durumda yerine getirmesidir. Görüşmeler esnasında Suriyeli kadınların eşleri, Türk kadınlarının Suriyeli kadınlar kadar uysal olmadığı, dik başlı ve söz dinlemez olduklarını bu sebeple Suriyeli eşleriyle daha mutlu ve huzurlu bir aile ortamı sağladıklarını ifade etmişlerdir.

\subsection{Suriyeli gelinlerin sosyal hayata ve mekâna uyumu}

Dünyanın hemen her yerinde kadınlar, coğrafi mekânlarda erkeklerden daha dezavantajlı durumda bulunmakla birlikte mekânsal kısıtlılığı fazlasıyla yaşamaktadırlar. Kadınlar daha çok evleri, sokakları, mahalleleri ve çalışma mekânlarında etkin bir hareketliliğe sahiptirler. Bu mekânlar dışındaki yerlerin imkân ve firsatlarının farkında 
olmayan kadınlar, kendilerine oluşturdukları kısıtlı yaşam alanlarında kendi yetenekleri ve yeterliliklerinin farkına varmadan dışa kapalı bir hayat sürmektedirler (Harunoğulları, 2016:388;389).

Evlilik yeni güvenli yaşam alanı inşa etmenin yollarından biridir. Savaşla birlikte aile dinamikleri değişime uğramıı̧tır. Savaşın parçaladığı, ölümlerin ve korkuların sizi hedef aldığı bir ülkeden kaçarak mülteci olma ve ev sahibi ülkede yeni bir günlük yaşam inşa etme ve onu sürdürmeye çalışma, koşullara göre sosyal hayatı yeniden inşa etme ve şekillendirme hiç de kolay değildir. Yeni bir hayatı sürdürmeye çalışırken evlilikle birlikte Suriyeli kadınlar için eşleri tarafından yeni bir yaşam alanı inşa edildiği gibi aynı zamanda yeni sosyal bağlarla birlikte hayat yeni bir anlam kazanmaya başlamıştır.

"ilk eşim teyzemin oğluydu. 4 yll evli kaldık, sorumsuz bir insandl, çalışmazdl, beni döverdi, kaynanam bana sürekli olarak psikolojik şiddet uyguluyordu. İlk eşimden bir kızım var. Daha fazla dayanamadım ondan ayrldıı. Halep'teyken Esad bizi bombaliyordu. Şimdiki eşimden ve ailesinden memnunum. İlk eşimden ayrlldıtan 5 yll sonra ikinci evliliğimi yaptım. Şu anki eşimin ailesiyle uyumluyuz problem yaşamıyoruz. Annem ve kardeşlerim Istanbul'da, gidip onları görebiliyorum. Kilis'te her bakımdan rahat yaşıyorum. Eş̧im tarafindan kisıtlanmiyorum. Kilis kültürü̈ne alıştım, giyim, yeme-içme, çarşs-pazara gitme, kendimi ifade etmede sorun yaşamıyorum. Maddi durumumuz kısıtlı ama ona rağmen hayatımdan oldukça memnunum. Komşularımla iyi anlaşlyorum. Suriye benim vatanım, doğup büyüdüğüm yer ama Kilis'te yaşamaktan memnunum." (K3).

Ev sahibi toplumda aidiyet duygusu arayan Suriyeli kadınlar için evlilik, onlara toplumla bağ kurmada ve mekâna ait hissetmede yardımcı olmakta ve kendilerini topluluğun bir üyesi olma sürecini kısalmaktadır. Yapılan evlilikler, aile kuran kadınların geldikleri şehre/mekâna uyum sağlaması, kabul görmesi, kendini yaşadığı yerde güvende hissetmesi, aidiyet bağı kurması, değer görmesi sürecini olumlu etkilemiştir.

“Memleket özlemim yok. Halep'te bombalar atılmış tüm şehir harabeye çevrilmiş. Bombalarla yıklan, harabeye dönen, ölümlerin yaşandığı o yere gitmek istemiyorum. Kilis'i daha çok seviyorum. Burada kendimi güvende ve huzurlu hissediyorum." (K7).

Kilis şehrinde yaşayan Suriyeli kadınlarla yapılan görüşmeler neticesinde farklı etnik ya da kültürlerdeki bireylerle evlenenler olduğu gibi aynı etnik köken ve kültüre sahip bireylerle evlilik yapanlar da söz konusudur. Görüşme yapılan Suriyeli kadınların hiç birinin evlendikleri erkeklerle akrabalık bağlarının olmadığı tespit edilmiştir. Kilisli vatandaşların bir kısmı ile Suriye'nin kuzey yerleşmelerinde yaşayan Suriyeli vatandaşların akrabalık bağları da bulunmaktadır. Kilis'in bir sınır ili olması ve aynı zamanda Suriye ile tarihi, kültürel ve akrabalık bağlarının bulunması nedeniyle Suriye iç savaşı öncesinde de Kilisli erkeklerin Suriyeli kadınlarla evlilikleri söz konusudur. Suriye iç savaşından sonra Kilis'e yerleşen Suriyeli nüfusun çokluğu nedeniyle evliliklerde artış yaşanmıştır. Görüşme yapılan Suriyeli kadınların evlilik yaptığı Kilisli erkeklerin bekar veya önceki evliliğini yıllar önce bitirmiş olması dikkat çekmiştir. Sosyal medyada ve yazılı basında Suriyeli kadınların daha çok kuma olarak yer aldığı haberlerin çokluğu tüm Suriyeli kadınların ikinci eş olduğu yönünde bir algı oluşturmuştur. Yaptığımız saha çalışmasında görüşme yaptığımız tüm Suriyeli kadınların evlendikleri erkeklerin bekar olması ve hem dini hem de resmi nikah işlemleri yaptıkları belirlenmiş̧tir. Suriyeli kadınlardan 3'ünün, evlilik yapılan eşlerden 7'sinin ikinci evliliğidir (Tablo 3).

Tablo 3. Eşlerin kaçıncı evliliği olduğu ve çocuk sayıları

\begin{tabular}{lccccc}
\hline Katılımc1lar & $\begin{array}{c}\text { Suriyeli gelinin } \\
\text { kaçınc1 evliliği }\end{array}$ & $\begin{array}{c}\text { Eşinin kaçınc1 } \\
\text { evliliği }\end{array}$ & $\begin{array}{c}\text { Suriyeli gelinin } \\
\text { ilk evliliğinden } \\
\text { olan çocuk sayıs1 }\end{array}$ & $\begin{array}{c}\text { Eşinin ilk evlili- } \\
\text { ginden olan ço- } \\
\text { cuk sayıs1 }\end{array}$ & $\begin{array}{c}\text { Eşlerin ortak ço- } \\
\text { cukları }\end{array}$ \\
\hline K1 & 1 & 2 & - & 2 & - \\
K2 & 2 & 2 & 2 & 6 & 1 \\
K3 & 2 & 2 & 1 & 4 & 1 \\
K4 & 1 & 2 & - & 4 & - \\
K5 & 1 & 2 & - & 2 & - \\
K6 & 1 & 1 & - & - & - \\
K7 & 1 & 1 & - & - & - \\
K8 & 2 & 2 & - & - & - \\
K9 & 1 & 1 & - & - & - \\
K10 & 1 & 2 & - & - & - \\
K11 & 1 & 1 & - & - & - \\
K12 & 1 & 1 & - & - & - \\
K13 & 1 & 1 & - & - & - \\
K14 & 1 & 1 & - & & - \\
K15 & 1 & 1 & & - & - \\
\hline
\end{tabular}


Genelde eşlerin ilk evliliklerinden olan çocukları babaanne tarafından bakılmaktadır. İkinci evliliğini yapmış olan Suriyeli kadınların ilk eşlerinden olan çocukları kendileriyle yaşamakta ve şimdiki eşleri tarafindan kendi çocukları gibi görülmektedir.

\begin{abstract}
"Illk eşimden de ikinci eşimden de memnun kaldım. Ancak bu eşim bana daha iyi davranıor. Bana değer veriyor. Bu eşimden daha memnunum. İlk evlendiğim zamanlarda Türkçe bilmiyordum. Çok zorlandım. Şimdi Türkçe anlıyorum az da olsa konuşabiliyorum. Çocuklarımı kendi kültürümle büyütmek istiyorum. Onları okutmak istiyorum. Kilis'te evlendiğim kocam hayatıma anlam katt. Illk eşimden olan çocuklarım Kilisli eşime baba diye sesleniyor. Onu kendi babaları yerine koydular. Eşim de çocuklarıma baba şefkatini veriyor. Onları kendi çocuklarımış gibi seviyor.” (K2).
\end{abstract}

Yapılan görüşmelerde Suriyeli kadınların eşinin kayınvalideleriyle uyumlu bir ilişki kurdukları her iki tarafından birbirlerinden razı oldukları ifade edilmiştir. Ayrıca daha önce Suriye'de evlilik yapmış ve eşini savaş sebebiyle kaybetmiş veya ilk eşinden ayrılmış olan Suriyeli gelinler, Türk kayınvalidelerinin Suriyeli kayınvalidelerden daha anlayışlı olduğunu onlarla ilişkilerinde sorun yaşamadıklarını belirtmişlerdir. Suriye'de sosyal hayata kısıtlı bir şekilde katılan Suriyeli gelinler, Kilis’te özgürce hareket ettiklerini kendilerini güvenli hissettiklerini ifade etmişlerdir.

"Kendi isteğimle evlendim. Eşimin bir akrabası ile halamın tanıdı̆̆l sayesinde eşimle tanıştım. Bir ablam Lazkiye'de evli, annem babam ve diğer kardeşlerim ise Kilis'te yaşıyor. Şu anki eşimin ikinci karısııım. Benim de ikinci evliliğim. Illk eşimle Suriye'de 5 yll evli kaldım, çocuğu olmayınca kocam üzerime kuma getirdi. Durum zorlaşınca kocamdan boşandım. Şimdiki eşimin ilk evliliğinden 2 çocuğu var. Çocuklar babaannede kalıyor. Eşimin ailesiyle ayrı yaşlyoruz, bizim kendi evimiz var. Maddi olanaklarımız kısıtlı ama yine de mutluyum. Kaynanam, Suriye'deki kaynanamdan daha iyi, onunla anlaşlyoruz. Ailemle görüşebiliyorum. Suriye'deyken evden dışarı çıkamazdım. Kilis'te tek başıma sokağa çıkıyor, ihtiyaçlarımı kendim alıyorum. Giyim ve yemekler konusunda sorun yaşamadım. Kilis'teki yaşantıya ve kültüre alıştım. Kendi yöresel yemeklerimizi çok az pişiriyorum. Herhangi bir işte çalışmak istemezdim. İhtiyacım olduğu zaman eşimden harçlık alırım. Kilis'e kendimi ait hissediyorum. Herhangi bir sıkıntı yaşamadım. Uyum sağlayabiliyorum. Komşularımızla ilişkilerimiz iyi birbirimize gidip geliyoruz. Suriye'deyken eşim ticaretle uğraşıyordu. Başka şehirlere gidiyordu ben evde tek başıma kalıyordum. Dışarı çıkamıyordum, eşim ailemin bize gelmesini istemiyordu. Evde çok bunalıyordum, buradaki eşimden daha çok memnunum, bu eşim daha iyi, beni istediğim şekilde gezdiriyor, istediğim şekilde rahat yaşıyorum. Bir çocuğum oldu. Suriye'de hiç güzel bir evim olmadı, burada rahatım, huzurum yerinde, artık burası benim vatanım.” (K8).

Suriyeli kadınlar kendi istekleri doğrultusunda sosyal hayata dâhil olmaktadırlar. İstedikleri gibi giyinmekte ve Suriye'deki gibi giyim konusunda kendilerini baskı altında hissetmemektedirler. Ev ihtiyaçları için kendileri çarşı-pazara çıkma konusunda sorun yaşamamaktadırlar. Aileleriyle özgürce görüşebilmekte farklı şehirlerdeki aile bireylerini ziyaret etmek istedikleri zaman eşleri bu konuda onlara destek olmakta aile ziyaretlerini birlikte yapmaktadırlar. Kayınvalideleri veya eşinin ailesinin diğer kadınlarıyla komşu ziyaretleri yapmakta, Türk yemeklerini öğrenmektedirler. Ayrıca kendi mutfak kültürlerini de yaşatmaktadırlar. Araştırmada komşuluk ilişkileri geliştiren Suriyeli gelinlerin yaşadıkları eve, mahalleye ve şehre karşı aidiyet duygusunun geliştiği tespit edilmiştir. Şehre ve yaşadıkları çevreye karşı olumlu duygular beslemektedirler.

"Benim ilk evliliğim. Eşimin ikinci evliliği. Kocam ilk eşiyle 12 yll evli kalmış ilk eşinden boşandıktan 7 ay sonra benimle evlendi. Eşinin ailesiyle aynı binada iki ayrı dairede oturuyoruz. Eşimin kızıla çarşıya pazara rahatlıla çıkabiliyorum. Kilisliler gibi giyiniyorum. Kilis'e geldikten sonra yemek yapmayı öğrendim. Kilis yemeklerine ve yaşam tarzına alıştım. Illk zamanlar Türkçe öğrenmeyi istemedim, eşime ve eşimin çocuklarına Arapça ögrettim, onlarla Arapça anlaşlyorum. Ama yavaş yavaş Türkçe konuşmaya başladım. Eşimin ailesiyle herhangi bir anlaşmazlı̆̆ımız olmadı. Kilis'e kendi isteğimle geldim, kendimi buraya ait hissediyorum. Mahallede komşularımla anlaşlyorum. Herhangi bir uyum problemi yaşamadım. Kayınvalidemle birlikte Türk komşularıma ziyarete gidiyorum. Arap komşularımı tek başıma ziyaret ediyorum. Eşimin çocuklarıla babaanneleri ilgileniyor." (K4).

"Kendi isteğimle evlendim. Hem benim hem de eşimin ilk evliliği. Eşimin ailesiyle, komşularlyla uyumluyuz. Sorun yaşamıyoruz. Kendimi Kilis'e ait hissediyorum. Kilis kültürünü kolayca benimsedim. Suriye vatanım ama burası da artık benim için vatan." (K6).

Suriye'de savaşın getirdiği tüm olumsuzluklardan kaçmak ve kendi hayatlarını daha yaşanabilir bir hale getirmek adına yapılan evliliklerde maddi açıdan orta gelir seviyesinde olmalarına rağmen eşlerinin maddi durumları Suriyeli gelinler için yeterli gelmektedir. Harcamalarını eşlerinin gelir seviyesine göre düzenlemekte, eşlerine bu Copyright (C) 2021 by IJSSER 
konuda destek olmaktadırlar. Suriyeli gelinlerden 5'i uygun iş olursa çalışabileceklerini diğerleri ise eşlerinden harçlık aldıklarını ev işleriyle ilgilenmeyi yeterli gördüklerini belirtmişlerdir. Eşleri ve eşlerinin aileleri tarafindan birey olarak değer görüyor olmaktan memnuniyet duymaktadırlar. Akrabalık bağlarını geliştirmedeki rollerinin gereğini yerine getirmektedirler. Suriyeli gelinler Türk vatandaşı bir kişinin nüfusuna geçerek, sınır-ötesi evlilikten ötürü gerçek ailesinden kaybetmiş olduğu hakları, yeni ailesi üzerinden tekrar kazanmaktadır.

\section{Sonuç ve tartışma}

Kilis’te yaşayan Suriyeli kadınlarla yapılan görüşmeler sonucu elde edilen verilere göre, ataerkil bir aile yapısına sahip olan Suriye toplumunda kadınların yaşam şartları şehir ve kırsal yerleşmeler göre farklılık göstermektedir. Kırsal yerlerde yaşayan kadınlar, şehirde yaşayan kadınlara göre daha fazla kısıtlanmakta şehirlerdeki kadınlar daha özgür bir hayat sürmektedirler. Suriye'de kırsal yerlerde yaşayan kadınlar üzerinde geleneksel yaşamın etkisi giyim tarzı, eğitim durumu, çalışma şartları, erken yaşta evlilik, çok eşlilik gibi sosyal hayatı etkileyen pek çok alanda kendini göstermektedir. Kırsal kesimde kadınlar dış mekânlarda çarşaf giymeyi tercih ederken şehirlerde giyim tarzı ve kıyafet tercihleri aile yapısına göre değişebilmektedir. Kadınlar eğitim hakkına sahip oldukları halde her istediği işi yapabilme gibi bir tercihe sahip değillerdir. Kırsal kesimdeki kadınlar zor ekonomik koşullar nedeniyle aile işlerinde (tarım, bağ-bahçe işleri) kayıt dışı ve ücretsiz bir şekilde çalışmaktadırlar. Suriye toplumunda genç yaşta evlilikler ve çok eşlilik sık rastlanan bir durumdur. Kırsal yerlerde 13-14 yaş gibi erken bir dönemde kız çocukların evlilikleri söz konusu olurken şehirlerde eğitim gören kız çocuklarının evlilik yaşı 18 ve sonrasında gerçekleşebilmektedir. Özellikle kırsal kesimde yaşayan ailelerde eğitimini sürdürmek istemeyen kız çocukları küçük yaşlarda evlenerek aile sorumluluğunu almaktadır.

Suriye'deki iç savaş ve güvensizlik ortamı, aile ve akrabalarda meydana gelen kayıplar, temel ihtiyaçlara erişimde yaşanan sıkıntılar kadınların hayatlarında büyük sorunlara neden olmuştur. Aile bireylerinin gözaltına alınması, işkence görmesi, güvenlik, barınma, gıda, temiz su, elektrik gibi temel ihtiyaçların karşıllanamaması, güvenlik endişeleri, tecavüz, taciz gibi onura dokunacak şiddet tehdidi kadınların göç kararı almasında önemli etkenler olmuştur. Eşleri ölen veya savaşta kaybolan herhangi bir sebeple eşi olmadan göç etmek zorunda kalan kadınların hayata tutunmaları da güç olmaktadır. Suriyeli kadınların karşılaştıkları ilk zorluk konak ülkeye varmak, çocuklarının başını koyacağı yaşayacak bir yuva bulmaktır. Bilinmedik ve alışılmadık bir yerde güvenli bir çevre bulmak önceliktir. Sınırlı kaynaklar ve barınma sorunları yeterli gıdaya ulaşım imkanları onlar için en temel ihtiyaçlardır. Kadınlar savaşın kendi üstlerinde meydana getirdiği travma ve psikolojik sorunlar, şiddet gibi nedenlerle erkeklere göre ruhen daha büyük bir bunalım ve sıkıntı altında bulunmaktadırlar.

Suriyeli savaş mağdurları kötü yaşam koşulları, güvenlik endişeleri, kira ödeyememe ve akrabalarıyla yaşadıktan sonra kendi yerlerine taşınmaları nedeniyle ev sahibi ülkede çevrelerindeki topluluktan izole bir yaşam süren insanlar olmuşlardır. Ev sahibi topluma yabancı olan kadınlar, güvensizlik içinde ve artan sorumluluklarla birlikte kendilerinin, akrabalarının, çocuklu olanlar çocuklarının güvenliği için endişe duymuşlardır. Fiziksel şiddetten ve tacizden korkmuşlardır. Ev sahibi toplumda çocuklarıyla yalnız kalan ve yaşam mücadelesi veren kadınlar çocuklarının hayatlarının nasıl olacağından ve çektikleri duygusal sıkıntıdan dolayı endişe yaşamışlardır. Birçok Suriyeli kadın sığındıkları ülkede yaşama tutunmada büyük bir mücadele örneği göstermiş̧tir.

Saha çalışmasında görüşmeciler arasında, medyada sıklıkla dile getirilen çok eşli evliliklerle karşılaşıımamıştır. Türk erkekler ile evlilik yapan Suriyeli kadınlardan 7'sinin ikinci evliliğidir. Bu kadınlar, kendileri gibi ilk eşlerini kaybeden veya yıllar önce onlardan ayrılan Türk erkekler ile evlilik yapmışlardır. Yapılan görüşmelerin hepsinde evliliklerin bürokratik engellerden ötürü imam nikahlı yapıldığını ancak resmi nikah işlemleri için Suriye'deki kurumlardan yasal belgelerini edinmek kadınlar için zahmetli ve uzun zaman almış olsa da yasal belgeler edinildikten sonra çiftlerin resmi nikah için başvuruda bulundukları bazı görüşmecilerin resmi evlilik cüzdanını aldığı belirlenmiştir.

Kilis’te yerli erkeklerle evlilik yapan Suriyeli kadınların Türk erkeklerini tercih nedenleri arasında daha önce evlilik yapan ve eşinden bir sebeple ayrılmış (ölüm veya boşanma) olanların kendilerine ve ilk eşlerinden olan çocuklarına daha güvenli ve mutlu bir gelecek sağlama isteğidir. Ayrıca Türk erkeklerle ilk evliliklerini yapan Suriyeli kadınlar için de aynı durum söz konusudur. Bunlara ek olarak Suriyeli kadınlar yaşadıkları ekonomik sıkıntılardan, güvensizlik duygusundan kurtulmak, ailelerine sosyal ve ekonomik anlamda yardımcı olmak ve yaşadıkları ortama daha kolay uyum sağlamak, huzurlu ve mutlu bir aile kurmak isteği de evlilik kararı almalarında etken olmuştur.

Suriyeli kadınların bir kısmının eğitim seviyesi eşlerinden yüksek olsa da bu onlar için bir sorun teşkil etmemektedir. Eşleri ile aralarında yaş farkı bulunması da onlar için önemli değildir. Suriyeli kadınlar eşlerinin aile 
bireyleriyle ve komşularıyla uyumlu bir yaşam sürmektedirler. Kilis’te daha özgür, rahat, huzurlu ve güvenli bir ortamda yaşamak onlar için oldukça önemlidir. Daha önce Suriye'de evlilik yapmış olan kadınlar önceki eşleri ve ailelerini şimdiki eşleri ve aileleri ile kıyaslarken şu anki eşlerinden ve eşlerinin ailelerinden, yaşadıkları ortamdan ve yaşam şartlarından çok daha fazla memnuniyet duymaktadırlar. Yaptıkları evliliklerle kendilerine yeni bir gelecek yeni bir hayat kuran, yaşadıkları şehri kendilerine yurt yapan Suriyeli kadınların ülkelerine geri dönme gibi bir düşünceleri de söz konusu değildir.

\section{Yazarların katkı oranı beyanı}

Makalenin tüm aşamalarından yazar sorumlu olduğunu beyan eder.

\section{Çıkar Çatışması}

Bu çalışmada yazar tarafından herhangi bir çıkar çatışması belirtilmemiştir.

\section{Etik Kurul Onayı}

Araştırmanın verileri 2020 yılından önce toplanmıştır. Tüm sorumluluk araştırmacıya aittir. Tüm taraflar kendi özgür iradeleriyle araştırmaya dâhil olmuşlardır.

\section{Kaynakça}

Akyüz, S. ve Tursun, Ö. (2019). When Syrian 'girls' meet turkish 'boys': mapping gendered stories of mixed marriages, Middle East Critique, 28 (1), 29-49, https://doi.org/10.1080/19 436149.2018.1549215.

Cankurtaran, Ö., Albayrak, H. (2019). From Syria to Turkey: Being a woman, (Ed: Özvarış, Bahar ve Erdost, Türküler), Elma Teknik Basım Matbaacılık, Ankara.

Doumato, E. A. (2010). Syria, chapter in Women's Rights in the Middle East and North Africa: Progress Amid Resistance, ed. Sanja Kelly and Julia Breslin (New York, NY: Freedom House; Lanham, MD: Rowman \&Littlefi eld, 2010), http://www.freedom house.org.

Fiddian-Qasmiyeh, E. (2014). Gender and Forced Migration, in: Fiddian-Qasmiyeh, E., Loescher, G., Long, K. \& Sigona, N. (eds) The Oxford Handbook of Refugee and Forced Migrations Studies, pp. 395-408 (Oxford: Oxford University Press).

Gürpınar, B. (2017). Feminist uluslararası ilişkilerde güvenlik ve barış: Suriye iç savaşı ve kadınlar. Alternatif Politika, 9 (3): 471-494.

Harunoğulları, M. (2016). Suriyeli sığınmacıların Kilis şehrindeki mekânsal, kültürel ve ekonomik etkileri. Uluslararası Sosyal Araştırmalar Dergisi, 9 (45), 373-396. ISSN: 1307-9581. Doi Number: http://dx.doi.org/10.17719/jisr.20164520617.

IOM. (2020). World migration report 2020, https://publications.iom.int/system /files/pdf/wmr2020.pdf.

Landfino. (2018). Report Syria: Marriage legislation and traditions, 22 August 2018. Oslo, Norway.

Mahler, S.J. ve Pessar, P. R. (2001). Gendered geographies of power: Analyzing Gender Across Transnational Spaces. 7:4, 441-459, DOI:10.1080/1070289 X.2001.9962675

Personal Status Act No. 59 of 1953, https:/www.global-regulation.com/translation/syria/ 3370708/law-59-of-1953-personalstatus-law.html.

Sam, D. L. (2006). Acculturation of ımmigrant children ısland women. in David L. Sam ve John W.Berry, Acculturation Psychology (pp. 403-418). Cambridge University Press, Cambridge.

Syrian Network for Human Rights, (2020). http://sn4hr.org/syria-map-snhr/2020

TÜİK, (2020). Evlenme ve boşanma istatistikleri. 2019, İstatistik Veri Portal1, https://data.tuik.gov.tr/Bulten/Index?p=Evlenme-ve-Bosanma-Istatistikleri-2019-33708

UNHCR. (2020). Situation Syria regional refugee response. http://data2.unhcr.org/en/situations/syria

Ülgül, M. (2017). Suriye iç savaşına feminist bir yaklaşım. Alternatif Politika, 9 (3): 442-470. 


\section{Extended Abstract}

\section{Introduction}

Many factors such as economic factors, people's demands for equal rights, freedom and democracy, foreign interventions were effective in the outbreak of the civil war in Syria. During the civil wars, the civilian population is more exposed to conditions that increase the risk of death, injury, disability and disease in the country at different degrees. In the long-lasting bloody civil wars, large masses of population become refugees by having to leave the places where they live in order to have dignified, safe and better living conditions. Since the start of the civil war in March 2011, millions of Syrians have had to leave their homeland and their homes and migrate to neighboring countries as well as North Africa (especially Egypt) and European countries. With a population of 7.2 million $(7,245,754)$, Syria is the country of origin with the largest number of refugees globally, with the largest number of displaced persons. In the ninth year of the war, 13.5 million Syrians became in need of humanitarian aid within the country. According to the United Nations High Commissioner for Refugees (UNHCR), approximately 5.7 million Syrians have migrated to Turkey, Lebanon, Jordan, Egypt, Iraq, and 6.6 million have been displaced within Syria. 2.98 million people have become struggling to survive in hard-to-reach and besieged areas. Meanwhile, around one million have sought refugees in Europe. With approximately 3.7 million people $(3,626,734)$ in the world, the country hosting the highest number of Syrians is Turkey (UNHCR, 2020; IOM, 2020).

\section{Methodology}

In this study, the war situation, escape from the war, migration and the marriage decisions taken by Syrian women refugees in the struggle to build a new life in the host society were evaluated in line with their own expressions. The study area is the city of Kilis, located on the Turkish-Syrian border. The data of the study were obtained through in-depth interviews with 15 Syrian brides who married Turkish men and participant observation technique during the field study conducted in the spring and summer months of 2019. Qualitative observation methods were applied in our study. Syrian brides were reached through local networks using the snowball method. Spouses of Syrian brides participated in some of the interviews. Their views were also taken regarding the decision to marry a Syrian woman, establish a family with her, and the harmony of family members with each other. Since 5 of the Syrian brides interviewed were Syrian Turkmen, they were spoken in Turkish. Communication was established with 10 other Syrian brides with the support of a female translator who speaks Arabic. The ages of the Syrian women participating in the study ranged from 17 to 40. Participants were also asked questions about the pre-war situation, migration, living in the host society and marriage, as well as questions about obtaining personal information. In order for the participants to feel comfortable answering the questions asked, the interviews were conducted in a conversational mood. In the study, their names were not used considering their safety and privacy. Participants are expressed as $\mathrm{K} 1, \mathrm{~K} 2, \mathrm{~K} 3 \ldots$.

\section{Results}

In armed conflicts, women are made more targets by the fighters and are forced to leave their homes and seek asylum. Civilian losses occur in wars or armed conflicts, and almost $90 \%$ of civilian casualties are women and children (Gürpınar, 2017: 474). It has been stated in the published reports that 28,394 of the 226,247 civilians killed in Syria from March 2011 to March 2020 were women. While 16,062 of them are adult women, 12,332 of them are girls under the age of 18. With the targeting of women, the damage caused by wars in societies has manifested itself at a much higher level (Syrian Network for Human Rights, 2020). Women who lived a comfortable life in the settlements where they lived before the war, who were supported by their close friends, relatives, families, social support networks and men who manage their homes, were suddenly deprived of all these support networks and started to struggle to survive alone or with their children in the face of difficult conditions. Findings regarding the reasons for migration of Syrian women in the interviews can be listed in 8 items.

These are;

1. The pressure of the totalitarian regime in their country

2. The desire to escape from the chaos and war environment in the country

3. Attacks of regime soldiers and terrorist organizations

4. Subjecting (or fear of) attacks and sexual abuse of women by regime soldiers and members of terrorist organizations

5. Increasing political profiling and arrests 
6. Torture and violence

7. Air strikes

8. The desire to live in peace in an environment of peace and security

Syrian women, who had to migrate from Syria to Turkey, preferred to marry with men from different cultures for reasons such as being accepted by the host society, having a safe and healthy living space, and overcoming economic difficulties. In the field study conducted in Kilis city, there are Syrian women who married for the first time, as well as women with children who have married in their own country before, but live alone due to the death of their husbands or divorce and have a second marriage in Turkey. Syrian families consider it appropriate to marry their daughters to local men in order for their daughters to have better living conditions due to the vital difficulties they face in the geography they live in. In this way, Syrian refugees also get the support of their groom from Kilis. In order to protect themselves from the disadvantages of the migration process, Syrian refugee women enter into marriages with men from the local community, both traditionally / religiously and legally. In the study, the reasons why Syrian brides marry Turkish men were collected under 7 headings. These are:

1. The desire for a safe life

2. Access to better living conditions

3. Social acceptance

4. Willingness to live freely

5. The desire of women with children to provide a safe future for their children

6. Turkish men are considered to be more understanding and sensitive than Syrian men

7. The desire to be valued by his husband

Marriage is one of the ways to build a new safe living space. Family dynamics have changed with the war. While trying to maintain a new life, a new living space was built by their spouses for Syrian brides with marriage, and at the same time, life began to gain a new meaning with new social networks.

\section{Conclusion and discussion}

The civil war and the insecure environment in Syria caused major problems in the lives of women, with the loss of families and relatives and the difficulties in accessing basic needs. The detention of family members, torture, inability to meet basic needs such as security, shelter, food, clean water and electricity, security concerns, rape, and the threat of violence that would touch dignity, such as harassment, have been important factors in the migration decision of women. The desire of Syrian women to get rid of the economic difficulties and feelings of insecurity, to help their families socially and economically, to adapt more easily to the environment they live in, to establish a peaceful and happy family are the most important factors in making a marriage decision. 